\title{
NOTES ON THE BIRDS OF MT. ROBSON PROVINCIAL PARK, 1970
}

by David Stirling, Department of Recreation and Conservation, Victoria, B.C.

These notes on 113 species recorded during one summer's intensive field work in Mt. Robson Provincial Park were part of a natural history survey initiated by the British Columbia Parks Branch which would be the basis for a nature interpretation program. An additional 11 species (five of which Riley recorded as breeding in the park) were observed just beyond the park's boundaries. Most of my observations were made at low elevations from the Yellowhead Pass on the Alberta border to the confluence of the Robson and Fraser Rivers near the park's western boundary, but late in July I spent four days in sub-alpine and alpine areas in the vicinity of Berg Lake, north of Mt. Robson.

The Yellowhead Highway runs for 40 miles in an east-west direction through the middle of the park. From the low Yellowhead Pass (3,711 feet) the highway follows the valley formed by Yellowhead Lake, Moose Lake and the Fraser River. Between Moose and Yellowhead Lakes there are several marshy areas, ponds, and muskegs where birds are abundant in number and variety. These areas are the "Marshes" frequently referred to in the annotated list.

At low elevations, lodgepole pine (Pinus contorta), white spruce (Picea glauca), trembling aspen (Populus tremuloides) and willows (Salix spp.) are the abundant tree species. There are also scattered Douglas fir (Pseudosuga menziesii), western white birch (Betula papyrifera), black cottonwood (Populus trichocarpa) and alpine fir (Abies lasiocarpa) in these mixed forests. At higher elevations and on north-facing mountain slopes alpine fir forms dense forests. White bark pine (Pinus albicaulis) is common near timberline. Black spruce (Picea mariana) forms thick groves in the muskegs. The mixed forest has a well developed understory of red-osier dogwood (Cornus stolonifera), thimbleberry (Rubus parviflorus), soopolallie (Sheperdia canadensis) and huckleberry (Vaccinium spp.). A narrow strip of typical Columbia Wet Belt Forest dominated by large western red cedar (Thuja plicata) and western hemlock (Tsuga heterophylla) is found in the vicinity of Mt. Robson Ranch and along the Robson River to Kinney Lake. Above 6,000 feet there are extensive alpine regions with meadows, bare rock and ice.

Information about the birds of the Canadian Rockies is meagre and in complete, and most of that which is available comes from the drier Alberta side of the Continental Divide (Cowan, 1955). The check-list of birds of Jasper National Park (1966) lists 194 species that have been reliably reported from that area.

For information about the birds of the western side of the Divide we must refer to the expedition of the Alpin Club of Canada in the summer of 1911 J. H. Riley, a member of the expedi. tion, collected or observed 78 specie in the Yellowhead Pass, Moose River and Mt. Robson region. Riley crosser the Yellowhead Pass into British Columbia on July 9, and did much of his work in the alpine and sub-alpine areas along the Moose River. He com ments on the scarcity of bird life along most of his route. My own ob. servations in the alpine and sub-alpinc areas west and north of Mt. Robsor agree with those of Riley but I founc birds abundant at lower elevations along the highway, particularly be tween Moose and Yellowhead Lakes and along the lower part of the Robsor River in the western part of the park an area not worked by Riley. Thrushes flycatchers, vireos and warblers wer singing and noticeable in June anc early July, but there was a sudder 
drop in volume and variety of bird counds after July 10 . There is no loubt that the month of June is the best time to visit the boreal forests in rder to make a survey of the breeding listribution and abundance of small passerines.

Riley records the following species which I did not see (species with astersk indicating either nests or young (een): White-winged Scoter, Hooded Merganser, Cooper's Hawk, Roughegged Hawk (a sight record on July 16 seems questionable and it is not cecorded on the Jasper National Park heck-list), Marsh $\mathrm{H} \mathrm{awk}$, Pigeon Hawk, Blue Grouse*, Willow Ptarmian*, Baird's Sandpiper, Bonaparte's Gull, Common Nighthawk, Arctic Three-toed Woodpecker, Mountain Bluebird, Water Pipit, Myrtle Warber, Gray-crowned Rosy Finch*, Savannah Sparrow, and Slate-colored Tunco*.

I arrived in the park too late to see pring migraton patterns, except that Western Grebes and Surf Scoters seen in Moose Lake on June 17, but not ubsequently recorded, seemed to indiate a movement of non-breeding vater birds through the pass.

Movements of birds were noticeable n the early fall. In late August, ducks ncreased in numbers and Canada Geese appeared. Magpies came in from the east to the park dumps and Clark's Nutcrackers became common at lower levations. Both Black and Vaux fwifts were seen more often. Flocks of mixed warblers were noticed, but lirections of movement could not be scertained. Small flocks of Robins, Cedar Waxwings and Pine Siskins, bviously on the move, were seen. At he end of August there was also an nflux of Sparrow Hawks and Sharphinned Hawks.

Cpecies observed in Mt. Robson Provincial Park in $\mathbf{1 9 7 0}$

Note: In the following list, an asterisk ndicates that either nests or young were seen; two asterisks indicate that fither singing males on territories or cerritorial behaviour were observed.

*Red-necked Grebe: A pair with one foung was seen on the marshes at the east end of Moose Lake, June 22. As many as eight birds were seen in July, and four or five were present in the same area throughout August.

**Horned Grebe: A pair in full breeding plumage was present on the marshes from June 20 to September 2 but no nest or young were seen.

Western Grebe: Six were seen on Moose Lake, June 17, and one on Kinney Lake, July 17. None was seen on Moose Lake after June 17 which seems to indicate that these birds were late non-breeding migrants on their way to the prairies.

Great Blue Heron: One at the east end of Moose Lake, August 19. I had reports of herons in this same area from park visitors and a CNR railway engineer. Several were seen in the Valemount marsh.

Canada Goose: Although this species was present all summer just across the divide in Jasper National Park, I had only two records for Robson Provincial Park: one on Yellowhead Lake, August 17, and 14 on Moose Lake, August 29.

*Mallard: About a dozen, including two broods, were regularly seen on the marshes.

Pintail: Three on the marshes on August 25.

Green-winged Teal: Two males were seen on the marshes, June 24.

Blue-winged Teal: One on the marshes, July 27.

Ring-necked Duck: One male on the marshes on June 20, and two pairs on June 24.

*Barrow's Goldeneye: Four females were on the marshes, June 20; one female with eight young on July 13 .

Bufflehead: Two males were seen on the marshes, June 20.

Harlequin Duck: One female was seen on Berg Lake on July 19 and again July 21.

Surf Scoter: An immature was seen on Moose Lake, July 17.

Common Merganser: Two were seen on the marsh, July 7, and two on Kinney Lake, July 17.

Goshawk: One was seen in flight on the Berg Lake trail, July 18.

Sharp-shinned Hawk: Three were seen in late August. 
**Red-tailed Hawk: Possibly the commonest raptor in the park. Ten were seen at widely scattered points along the valley during the summer.

Golden Eagle: Observed only twice; one near Berg Lake on July 19, and two over the high ridges south of Moose Lake on August 19.

**Osprey: Observed eight times, at Red Pass, Whitney Lake and Yellowhead Lake.

Sparrow Hawk: Individuals were seen at scattered points in June and July but there were more sightings in late August, apparently indicating a migratory route through the valley.

* Spruce Grouse: This species seemed to be scarce. A female and young were observed at Berg Lake, July 21 (three other sightings were reported by hikers.)

*Ruffed Grouse: Common in mixed forests. Males were heard drumming in late June, and several broods were seen.

*White-tailed Ptarmigan: Although this species was not seen by the writer, it undoubtedly occurs in suitable alpine habitat. Only one family group was, however, reported by hikers in the high country.

**Sora: This species was heard many times in the marshes from June 22 to early August.

American Coot: First noted on July 13. One was seen on Yellowhead Lake and three were seen on the marshes throughout August.

**Killdeer: One was seen at the gravel pit near Red Pass from June to August. Its actions indicated a nest nearby but none was found.

**Common Snipe: Snipe were seen and heard at the marshes throughout the summer.. One was seen flying over Red Pass, August 14.

**Spotted Sandpiper: This was a common species on the outwash plains of glacial rivers and rocky beaches.

Solitary Sandpiper: On July 28 one was seen at a woodland pond easit of Moose Lake.

Lesser Yellowlegs: Three were seen on mud flats at the east end of Moose Lake, July 27.
Pectoral Sandpiper: Two were with the Lasser Yellowlegs, July 27.

Long-billed Dowitcher: Three with other shorebirds at the east end of Moose Lake, July 27. Markings and call notes led me to identify them as $L$. scolopaceus.

Semipalmated Sandpiper: Three were seen with the other shore birds on the mud flats on July 27.

California Gull: Immature large "white gulls" were often seen in flight along the Fraser River. Highest number seen was a flock of 16 . Several of these gulls were identified as $L$. californicus. Ring-billed and Herring Gulls may also have been present.

Mourning Dove: On July 27 one was seen at the east end of Moose Lake. This was the only record for the park but doves were seen in Jasper and they were common at Valemount.

Great Horned Owl: The only owl recorded was a fresh road kill of this species picked up just east of Moose Lake on August 29.

**Black Swift: Two (or sometime four) were frequently seen over th nature house near the western entranc to the park throughout the summer Six were seen at Berg Lake, July 22 Eight were seen on August 28.

Vaux Swift: First seen August 1 at Red Pass; one over Robson Station August 15; and four at Red Pass August 25.

**Rufous Hummingbird: Commo from the valley bottom to sub-alpin meadows from June 17 to mid-August

**Belted Kingfisher: Scattered indi viduals were seen along Moose an Yellowhead Lakes.

Red-shafted Flicker: A scarce spe cies, local along the highway.

**Pileated Woodpecker: Two wer seen near the nature house, June 1: During July the species was hear several times.

**:Yellow-bellied Sapsucker: Sing] birds were seen and heard drummin in the vicinity of the nature house late June and early July.

Hairy Woodpecker: One record: or at the east end of Moose Lake, July 2 
Northern Three-toed Woodpecker: one record: an individual in a spruce rrove near Red Pass, July 29.

**Eastern Kingbird: A pair was present at the east end of Moose Lake rom June 20 to August 19.

**Traill's Flyeatcher: This flycatcher was seen and heard near Red Pass in Tune.

**Dusky Flycatcher, **Hammond's Flycatcher, **ast Flycatcher: All hree species were present in suitable abitat. They could be separated by voice and habitat in June. The Least was the commonest in the mixed forest if the valley, Hammond's was the carcest.

Western Wood Pewee: Heard in June. Scarce in the park but very common in the dry, open pine forests near valemount.

**Olive-sided Flycatcher: Scarce at ower elevations but common in old ourns at timberline and in open pine corests west of the park.

*Violet-green Swallow: Seen in mall numbers throughout the valley. isually in the vicinity of buildings.

**Tree Swallow: Moderately comnon, but less so and more scattered han Violet-green Swallows. Pair seen at a dead tree at the east end of Moose Lake in June and July.

**Bank Swallow: Common, but no hesting locations found.

**Rough-winged Swallow: Scattered airs were seen throughout the valley.

*Barn Swallow: Nests with young were seen at Robson Station, Robson Motor Village, and Red Pass.

*Cliff Swallow: There was a colony $f$ about 75 birds at Red Pass. Twelve ests were counted on the station uilding, others were seen under the aves of private houses.

*Gray Jay: Moderately common from valley bottom to timberline. Juvenile irds seen.

Steller's Jay: Two records: one June 19, and one August 19.

Black-billed Magpie: Although the magpie is very common in Jasper National Park it is scarce in Mt. Robson Park and absent in British Columbia north of the Dry Interior. One was seen at Robson Motor Village on
June 19, and no others were seen until August 28 when three appeared at a dump near Yellowhead Lake. These birds were possibly fall wanderers from east of the Continental Divide.

**Common Raven: Ravens were scarce until mid-July when they became increasingly common, particularly along the highway, and at garbage dumps. Groups of up to a dozen were seen in August.

**Common Crow: Very common along the highway and at dumps. A flock of 125 was seen at Red Pass, August 24.

Clark's Nutcracker: This species was fairly common in the high country at Berg Lake, July 18 to 21 . It was not seen at lower elevations until August 15 but in late August, Nutcrackers became fairly common along the ridges at lower elevations.

**Black-capped Chickadee: A moderately common species in mixed forests throughout the park.

* Mountain Chickadee: Only one record: a family group near Red Pass, July 23.

*Boreal Chickadee: Two family groups were seen in muskeg habitat, June 22 and August 9.

Red-breasted Nuthatch: A moderately common species at low elevations.

American Dipper: A Dipper was seen on the Robson River near the nature house, July 19

**Winter Wren: Found in the wet cedar-hemlock forest along the Robson River. Two records: June 19 and July 22.

Rock Wren: A pair was seen on the moraine at the toe of the Robson Glacier, July 19. This species is listed as accidental on Jasper National Park bird check-list.

**American Robin: A fairly common species throughout the park. Seen at timberline July 20. Small flocks were seen on the move in late August.

**Varied Thrush: Moderately common throughout the park and heard singing in June and early July.

**Hermit Thrush: A common species in sub-alpine forests. Common at timberline in the Berg Lake area, July 19 to 21 . 
**Swainson's Thrush: Common in mixed forests at lower elevations throughout the park.

Townsend's Solitaire: One bird was seen near Robson Meadows, July 2.

Golden-crowned Kinglet: Seen in Spruce groves in the valley but rather scarce.

**Ruby-crowned Kinglet: Singing June 17 and 18 but not recorded again in the park.

Bohemian Waxwing: Six were seen in a sub-alpine burn west of Berg Lake, July 19 and 21.

**Cedar Waxwing: A fairly common species. Flocks composed of both adults and juveniles were seen in late August.

**Common Starling: Small groups were seen at garbage dumps and occasionally elsewhere. Juveniles were seen.

**Red-eyed Vireo: Common at lower elevations throughout the park.

**Warbling Vireo: Common in mixed and deciduous forest throughout the valley.

**Tennessee Warbler: Seen and heard in June and early July. Seen migrating with other warblers in late August. A moderately common species but rather local.

**Orange - crowned Warbler: Seen during the breeding season, and on migration in late August, but rather scarce.

**Yellow Warbler: Local. Seen at Red Pass and east end of Moose Lake.

**Magnolia Warbler: A singing male was present in a small grove of white spruce near Red Pass from July 1 to July 11. A female was seen collecting insect larvae near here, July 10. Two were seen with other warblers, August 29.

*Audubon's Warbler: Common and evenly distributed in open coniferous woods from valley bottom to timberline. A nest was found near Red Pass 30 feet up a lodgepole pine.

**Townsend's Warbler : Fairly scarce and local. A total of four records between July 18 and August 29. A singing male seen in white spruce grove near Red Pass in late June.
Blackpoll Warbler: A male was seen in thick black spruce east of Moose Lake, June 22.

**Northern Waterthrush: Singing males were recorded in June and July near the nature house and at the east end of Moose Lake. One was seen at Red Pass, August 16.

**MacGillivray's Warbler: Common below the sub-alpine zone throughout the park.

**Common Yellowthroat: Recorded in the marshes, but not elsewhere, in June and July.

**Wilson's Warbler: A common species from the valley bottom to the stunted alpine firs at timberline.

**American Redstart: This was the commonest warbler in mixed and deciduous forests along the valley.

*House Sparrow: Found only at Red Pass where about a dozen birds nest in the buildings and Cliff Swallow nests.

*Red-winged Blackbird: There was a small colony in the marshes east of Moose Lake. Juveniles seen in August.

Brewer's Blackbird: This species was seen at Robson Meadows, Red Pass, and at the east end of Moose Lake in June and early July. None seen after mid-July.

*Brown-headed Cowbird: Females were seen at Red Pass in June. Eight juveniles were seen at Red Pass in late July, roosting in low willows along the river.

**Western Tanager: Moderaitely common in coniferous forests throughout the valley.

Evening Grosbeak: Heard several times in June and July. A flock of 20 seen in August.

Purple Finch: Seen at close range on the ground twice at Red Pass and once at the east end of Moose Lake.

**Pine Grosbeak: A pair was seen at Red Pass from June to September No other sightings.

Pine Siskin: Common, usually in small flocks, throughout the park.

Red Crossbill: Scarce until Augus when scattered small numbers appear. ed throughout the park. 
Species recorded outside the boundaries of Mt. Robson Provincial Park which might be expected within the Park.

American Bittern: One was seen in July in the marsh at Valemount, 10 miles west of the park. There is suitable habitat for this species at the east end of Moose Lake.

Marsh Hawk: Recorded in August at Valemount. Seen in the Robson area by Riley.

Prairie Falcon: One was seen on Canoe Mt. near Valemount, August 25, and another at Mt. Edith Cavell, Alberta, September 1.

Greater Yellowlegs: This was a common species in the marsh at Valemount in July and August.

Black Tern: A colony of 20 birds at Valemount. Young seen on the wing in late Tuly.

Common Nighthawk: Seen by Riley at Moose and Yellowhead Lakes. This was a comman species in the dry, open forests just beyond the park's western boundary.

Horned Lark: One was seen giving its flight song on Whistler Mountain, Jasper National Park on July 3. A flock of at least 100 was seen on Canoe Mt., near Valemount on August 25 and again on August 31.
Mountain Bluebird: Recorded by Riley. A common species in the Valemount area and in the vicinity of the town of Jasper.

Water Pipit: Recorded as breeding by Riley. I saw no pipits in the alpine areas near Berg Lake but young with parents were seen on Canoe Mt. in July.

Savannah. Sparrow: Recorded as breeding by Riley. I saw none in the park but I found pairs and individuals in high country on either side throughout the summer.

Lapland Longspur: The distinctive calls of Lapland Longspurs were heard among the Horned Larks on August 31. After some searching I was able to find four longspurs.

\section{LITERATURE CITED}

Cowan, I. McT. 1955. Birds of Jasper National Park. Wildlife Management Bull. Series 2.

Godfrey, W. E. 1966. The birds of Canada. Natl. Mus. Can. Bull. 203. Ottawa.

Munro, J. A. and I. McT. Cowan. 1947. A review of the bird fauna of British Columbia. Prov. Mus., Victoria.

Peterson, R. T. 1961. Field guide to western birds. Houghton Mifflin Co., Boston.

Robbins, C. S. et al. 1966. Birds of North America. Golden Press, New York.

Riley. J. H. 1912. Birds collected or observed on the expedition of the Alpine Club of Canada to Jasper Park, Yellowhead Pass and Mt. Robson region. Can. Alpine Journal. Special number. Alpine Club of Canada. Banff.

\section{INFORMATION WANTED ON COLONIAL BIRDS}

In Saskatchewan we have 15 species of birds that usually nest in colonies. For several of these species, the colony is essential for successful nesting. Small groups or single pairs usually fail to raise broods.

In the past, colonial nesting must have been advantageous for these birds, but in the face of increasing human pressure, it has placed several species in a very vulnerable position. With species like the White Pelican, Double-crested Cormorant, and Great Blue Heron, each colony represents a significant proportion of the total nesting population. This, coupled with the extreme nervousness of the birds, makes them particularly vulnerable to local catastrophes. A single ill-timed visit by a group of people can have disastrous effects when it leads to chilling of the eggs, predation by marauding gulls, or fatal sunburning of young birds.

Saskatchewan's bird colonies are a very significant percentage of the Canadian total. For example, in 1968, there were 6,600 White Pelican nests in this province, representing 47 per cent of all nests in Canada, according to Kees Vermeer (Distribution and size of colonies of white pelicans. Pelecanus erythrorhynchos in Canada. Can. J. Zool., 48:1029-1032). Therefore we have a serious responsibility for protecting these species. In the past this 
sponsibility has been neglected, and le situation is now becoming critical. nmediate action is required to counract the snowballing trend of nest ilure and colony abandonment.

As a first step, the Saskatchewan Iuseum of Natural History is underlking an inventory of all bird colonies Saskatchewan, and we are soliciting ssistance from the public. If you now of any nesting colonies of the oecies listed below, we would be most rateful if you would let us know. lease give us all the information you an without disturbing the colonies. Vith species other than gulls and rns, it is of utmost importance not disturb the colony.

The reports of greatest value are ose that include the names of the pecies in the colony, the exact location ff the colonies, and an estimate of he numbers of nests of each species.
Can YOU help us? Write to

Robert J. Long, Museum Assistant, Saskatchewan Museum of Natural History, Regina.

\section{Species of colonial birds found in Saskatchewan}

Western Grebe

Eared Grebe

White Pelican

Double-crested Cormorant

Great Blue Heron

Black-crowned Night Heron

Herring Gull

California Gull

Ring-billed Gull

Mew Gull

Bonaparte's Gull

Arctic.Tern

Common Tern

Forster's Tern

Caspian Tern

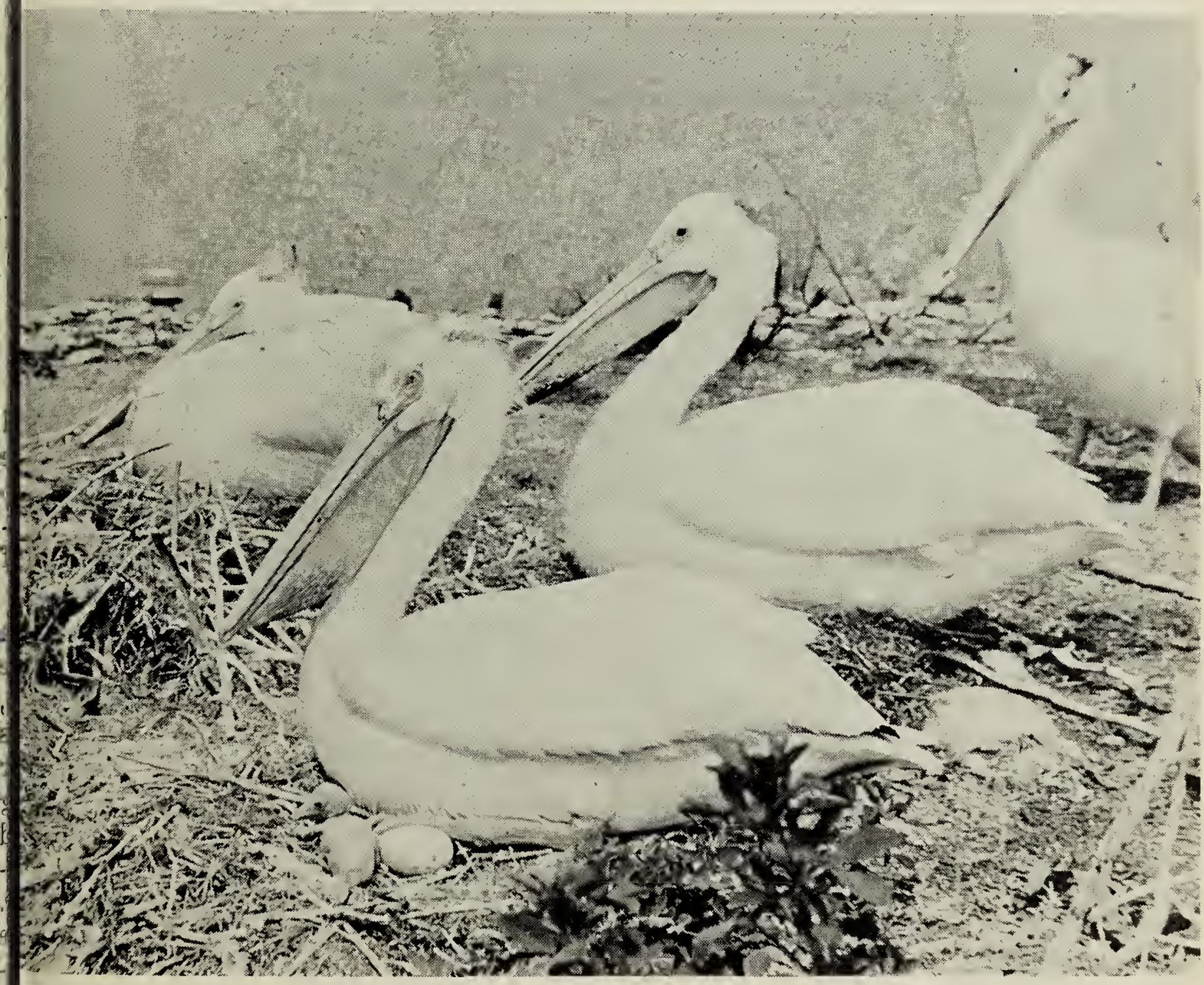

